\title{
Copper(II), nickel(II) and zinc(II) complexes of hexapeptides containing separate aspartyl and histidyl residues
}

\author{
Mária Raics $^{a}$, Daniele Sanna ${ }^{b}$, Imre Sóvágó $^{a}$ and Csilla Kállay \\ ${ }^{a}$ Department of Inorganic and Analytical Chemistry, University of Debrecen, $\mathrm{H}-4010$ \\ Debrecen, Hungary \\ ${ }^{b}$ Istituto di Chimica Biomolecolare, CNR, Traversa La Crucca 3, Regione Baldinca, $07040 \mathrm{Li}$ \\ Punti (SS), Italy \\ ${ }^{c}$ Research Group of Homogeneous Catalysis and Reaction Mechanism, Hungarian Academy \\ of Sciences, H-4010 Debrecen, Hungary
}

\begin{abstract}
Copper(II), nickel(II) and zinc(II) complexes of two N-terminally free and C-terminally blocked hexapeptides, $\mathrm{NH}_{2}-\mathrm{ADAAAH}-\mathrm{NH}_{2}$ and $\mathrm{NH}_{2}-\mathrm{AADAAH}-\mathrm{NH}_{2}$, containing separate aspartyl and histidyl residues have been studied by potentiometric, UV-vis, CD and ESR spectroscopic methods. The amino termini were found as the primary anchoring sites of both ligands for the complexation with all three metal ions. The $\beta$-carboxylate function of the second or third aspartyl residue enhances the thermodynamic stability of the copper(II) and nickel(II) complexes and shifts the deprotonation of the subsequent amide functions into a more alkaline $\mathrm{pH}$ range. In the case of $\mathrm{NH}_{2}-\mathrm{AADAAH}-\mathrm{NH}_{2}$ the imidazole-N donor of the histidyl residue does not have a significant contribution to the overall stability of the mononuclear complexes. The side chain imidazole, however, can be an independent metal binding site resulting in the formation of dinuclear or even mixed metal complexes. The stabilizing role of the histidyl residue is much more pronounced in the complexes of the $\mathrm{NH}_{2}$ ADAAAH-NH $\mathrm{N}_{2}$ peptide. In this case a tridentately $\left(\mathrm{NH}_{2}, \mathrm{~N}^{-}, \beta-\mathrm{COO}^{-}\right)$-coordinated species is formed and its stability is significantly enhanced by the macrochelation of the side chain imidazole. The presence of two anchoring sites (terminal amino and side chain imidazole) in one molecule enhances the stability of the corresponding zinc(II) complexes, too,but the amide nitrogens are not involved in metal binding in this case.
\end{abstract}

\section{Keywords}

copper(II), nickel(II), zinc(II), peptides, histidyl, aspartyl 


\section{Introduction}

Metalloproteins are molecules built up of various amino acidscontaining several functional groups. All of them may appear as independent metal binding sites. Typical examples are the prion proteins [1] and the amyloid- $\beta$ peptide [2] which readily form poly- and hetero-nuclear complexes with transition metal ions. Metal binding affinity of these functional groups significantly depends on the vicinity of the specific sites determined by the sequence of the peptide molecules.Oligopeptides with spatially separated binding sites serve as the simplest models for studying these effects [3,4]. These kinds of investigations are available for small peptides incorporating two or more separatehistidyl residues located in distinctenvironments [5-9]. These studies reveal that imidazole-N donor atoms of histidyl residues are effective metal binding sites at virtuallyany position of a peptide chain. On the other hand, the coordination chemistry of peptides containing histidine in the N-terminal or in the second, third or in a distant position is significantly different resulting in a great variety and high metal ion selectivity regarding the complex formation processes of various multihistidine peptides. It is also evident from these and some other literature studies that the presence of other functional groups may notably influence these processes [10-11]. Among them, the role of side chain $\beta$-carboxylate functions of aspartyl residues are especially striking.

Huge number of studies has already been performed on the transition metal complexes of peptides containing one to four aspartyl or glutamyl residues.At least three major conclusions can be drawn from these studies [4]: (i) in the case of terminally protected peptides neither aspartyl nor glutamyl residues are able to induce amide deprotonation and coordination in the copper(II) nickel(II) and zinc(II) complexes, (ii) the presence of side chain carboxylates enhances the thermodynamic stability of peptide complexes as compared to those of common peptides and this effect is especially pronounced for aspartyl residue, (iii) the stability increase significantly depends on the location of the aspartyl residue in the peptide chain. The impact of aspartic acid in a distant internal position on complexation is virtually negligible, whereas it has a considerable influence in the vicinity of the N-terminus. The pentapeptide fragment of thymopoietin provided the first evidence for the role of aspartic acid in position-3 from the N-terminus [12]. It was found that the coordination of $\beta$ carboxylate can block the copper(II) binding of the third amide functions and $\left(\mathrm{NH}_{2}, \mathrm{~N}^{-}, \mathrm{N}^{-}, \beta-\right.$ $\mathrm{COO}^{-}$) coordinated complexes were formed. Further studies on model peptides unambiguously supported these observations [13,14]. More recently, these effects were also detected in the case of polyaspartyl peptides [15] and even in the corresponding nickel(II) and palladium(II) complexes [16,17]. The stabilizing role of aspartyl residues in $2^{\text {nd }}$ position or in the $\mathrm{N}$-terminus was reported to be less effective but the stability enhancement was observed in all cases.

The number of studies on the metal complexes of peptides containing both aspartyl and histidyl residues is relatively low. Now in this paper we report the synthesis of two terminally free but $\mathrm{C}$-terminally blocked hexapeptides containing aspartic acid in the second or third position and histidine at the C-terminus, as well as the potentiometric and spectroscopic studies of their binary and ternary systems with copper(II), nickel(II) and zinc(II). The peptides $\mathrm{NH}_{2}-\mathrm{AADAAH}-\mathrm{NH}_{2}$ andNH $\mathrm{H}_{2}-\mathrm{ADAAAH}-\mathrm{NH}_{2}$ offera promisingchance 
for the comparison of the anchoring role of internal histidine residue and aspartic acid in the third and second position, respectively, in the same molecule.

\section{Experimental}

\section{Peptide synthesis, purification and other materials}

All solvents and chemicals of highest available purity used for synthesis and in the potentiometric and spectroscopic measurements were obtained from commercial sources and used without further purification.

Both N-fluorenylmethoxycarbonyl (Fmoc)-protected amino acids (Fmoc-His(Trt)-OH, FmocAla-OH and Fmoc-Asp(OtBu)-OH) and 2-(1-H-benzotriazole-1-yl)-1,1,3,3tetramethyluronium tetrafluoroborate (TBTU) were purchased from Novabiochem (Switzerland), while the Rink Amide AM Resin was Merck product. Peptide-synthesis grade $N, N$-dimethylformamide (DMF), $N, N$-diisopropyl-ethylamine (DIEA), 1,2-ethanedithiol and trifluoracetic acid (TFA) were obtained from Merck Kft, 1-hydroxybenzotriazole hydrate (HOBt $\cdot \mathrm{H}_{2} \mathrm{O}$ ), N-methyl-pyrrolidone (NMP), triisopropylsilane (TIS), 2,2'(ethylenedioxy)diethanethiol, diethyl ether $\left(\mathrm{Et}_{2} \mathrm{O}\right)$ and 2-methyl-2-butanol were SigmaAldrich products. Piperidine and dichloromethane (DCM) were Molar solvents as well as acetonitrile $(\mathrm{ACN})$ and acetic anhydride were from VWR.

The peptides $\mathrm{NH}_{2}-\mathrm{AADAAH}-\mathrm{NH}_{2}$ and $\mathrm{NH}_{2}-\mathrm{ADAAAH}-\mathrm{NH}_{2}$ were assembled by means of a microwave-assisted Liberty 1 solid phase peptide synthesizer (CEM, Matthews, NC), using the Fmoc/tBu strategy.

The first step of the synthesis was the deprotection of Rink amide resin $(0.71 \mathrm{mmol} / \mathrm{eq}, \mathrm{AM}$ Resin, 200-400 mesh)with a 20\% piperidine/DMF and $0.1 \mathrm{M} \mathrm{HOBt} / \mathrm{DMF}$ solution at $75^{\circ} \mathrm{C}$ with $35 \mathrm{~W}$ microwave power for $180 \mathrm{~s}$. In the next stage the Fmoc-protected C-terminal amino acid was bonded to the resin following the TBTU/HOBt/DIEA activation strategy (0.5 M HOBt/0.5 M TBTU/DMF and $2 \mathrm{M}$ DIPEA/NMP, using 4 times excess of amino acids, at $75^{\circ} \mathrm{C}$ with $25 \mathrm{~W}$ microwave power, for $300 \mathrm{~s}$ ) then the polymer-bonded amino acid was treated with $20 \%$ piperidine/DMF and $0.1 \mathrm{M} \mathrm{HOBt} / \mathrm{DMF}\left(75^{\circ} \mathrm{C}, 35 \mathrm{~W}\right.$ microwave power, for $180 \mathrm{~s})$ to remove the Fmoc protecting group. After the coupling of the second Fmocprotected amino acid to the first with TBTU/HOBt/DIEA, the cycle of deprotection and coupling was repeated as desired to add amino acids to the growing chain.

The prepared peptide linked to the resin was washed with dichloromethane, $96 \%$ acetic acid, 2-methyl-2-butanol and diethyl ether. Subsequent treatment with a mixture of TFA/TIS/ $\mathrm{H}_{2} \mathrm{O} / 2,2^{\prime}$-(ethylenedioxy)diethanethiol $(94 / 2.5 / 2.5 / 1 \mathrm{v} / \mathrm{v}) \quad$ for $2 \mathrm{~h}$ at room temperature cleaved the peptide from the resin as well as removed the side chain protective groups. The solution containing the free peptide was separated from the resin by filtration, followed by recovering from the pertinent solution by precipitation with cold diethyl ether. The precipitate was washed with cold diethyl ether, then was centrifuged and dried, redissolved in water and finally lyophilized. 
The purity of the peptides was checked by analytical rp-HPLC analyses using a Jasco instrument equipped with a Jasco MD-2010 plus multiwavelength detector [chromatographic conditions: column: Vydac C18 (250 x $4.6 \mathrm{~mm}, 300 \AA$ pore size, $5 \mu \mathrm{m}$ particle size), mobile phase A: $0.1 \%$ TFA in acetonitrile, mobile phase $\mathrm{B}: 0.1 \%$ TFA in water, flow rate: $1 \mathrm{~mL} / \mathrm{min}$, detection: $\mathrm{UV}$ at $222 \mathrm{~nm}, \mathrm{t}_{\mathrm{R}}\left(\mathrm{NH}_{2}-\mathrm{AADAAH}-\mathrm{NH}_{2}, 2 \% \mathrm{ACN}\right)=4.13 \mathrm{~min}, \mathrm{t}_{\mathrm{R}}\left(\mathrm{NH}_{2}-\right.$ ADAAAH-NH $\left.\left.\mathrm{N}_{2}, 2 \% \mathrm{ACN}\right)=3.33 \mathrm{~min}\right]$, while their identity was confirmed by ESI-MS experiments on a Finnigan LCQ-Duo ion trap electrospray mass spectrometer.

Concentrations of the peptide stock solutions were determined by potentiometric titrations that also supported the purity and the identity of the substances.

Stock solutions of metal ions were prepared from analytical grade reagents $\left(\mathrm{CuCl}_{2}, \mathrm{NiCl}_{2}\right.$ and $\mathrm{ZnCl}_{2}$ ) and their concentrations were checked gravimetrically via the precipitation of oxinates.

\section{Potenciometric measurements}

The $\mathrm{pH}$-potentiometric measurements were performed with a MOLSPIN pH-meter equipped with a 6.0234.100 combined glass electrode (Metrohm) and a MOL-ACS microburette controlled by a computer(in the $\mathrm{pH}$ range $2.5-11.5$ ).

The titrations were accomplished in $3 \mathrm{~mL}$ samples with peptide concentration of $\sim 2 \mathrm{mM}$, using carbonate free stock solutions of potassium hydroxide $(\sim 0.2 \mathrm{M})$. The metal ion to ligand ratios were selected as 1:2, 1:1 and 2:1 for binary systems and 1:1:1 for ternary systems.

During the measurements argon was bubbled through the samples to ensure the absence of oxygen and carbon dioxide. All pH-potentiometric measurements were carried out at a constant ionic strength of $0.2 \mathrm{M} \mathrm{KCl}$ and at a constant temperature $(298 \mathrm{~K})$.

The number of experimental points reached around 60 to $110\left(\mathrm{~cm}^{3}-\mathrm{pH}\right)$ for each titration curve. The recorded $\mathrm{pH}$ values were converted to hydrogen ion concentration as described by Irving et al. [18]

Protonation constants of the ligands and the overall stability constants $\left(\log \beta_{\mathrm{pqr}}\right)$ of the complexes were calculated by means of the general computational programs [19], (PSEQUAD and SUPERQUAD) based on eqn (1) and (2).

$$
\begin{gathered}
\mathrm{pM}+\mathrm{qH}+\mathrm{rL}=\mathrm{M}_{\mathrm{p}} \mathrm{H}_{\mathrm{q}} \mathrm{L}_{\mathrm{r}} \\
\beta_{p q r}=\frac{\left[M_{p} H_{q} \mathrm{~L}_{r}\right]}{[M]^{p} \cdot[H]^{q} \cdot[\mathrm{L}]^{r}}
\end{gathered}
$$

\section{Spectroscopic studies}


UV-Vis spectra of the complexes were recorded on Hewlett Packard HP 8453 diode array and Perkin Elmer Lambda 25 double beam spectrophotometers. CD-spectroscopic studies were performed using a JASCO J-810 spectropolarimeter (cell length: 1 and/or $10 \mathrm{~mm}$, wavelength range: $200-800 \mathrm{~nm}$ ).

Frozen solution EPR spectra were recorded on a Bruker EMX spectrometer, equipped with a HP 53150A microwave frequency counter at $120 \mathrm{~K}$. Copper(II) stock solutions for EPR measurements were prepared from $\mathrm{CuSO}_{4} \cdot 5 \mathrm{H}_{2} \mathrm{O}$ that had been enriched with ${ }^{63} \mathrm{Cu}$ to achieve higher resolution spectra. Metallic copper $\left(99.3 \%{ }^{63} \mathrm{Cu}\right.$ and $0.7 \%{ }^{65} \mathrm{Cu}$ was purchased from JV Isoflex (Moscow, Russia) for this purpose and was then converted into the sulfate. Stock solution of naturel copper(II) was used to record the spectra of high $\mathrm{pH}$ samples.

For all spectroscopic measurements the concentration of the samples was the same as used for pH-potentiometry.

\section{Results and discussion}

\subsection{Protonation equilibria of the peptides}

The protonation constants of the ligands were determined by $\mathrm{pH}$-potentiometric measurements and the $\mathrm{pK}$ values are included in Table 1 together with the stability constants of the metal complexes.It is clear from Table 1 that both peptides have 3 protonation siteswhich can be assigned to the terminal amino group,the side chain imidazole and $\beta$ carboxylate functions. There are no significant differences between the protonation constants of the two peptides which demonstrate a good agreement with our expectations since identical protonation sites are present in both molecules in similar environments. The protonation of the $\beta$-carboxylate functions occurs in the acidic $\mathrm{pH}$ range and separates well from those of the nitrogen donors. There is a slight overlap in the protonation of the side chain imidazole and terminal amino groups but the comparison of these values with those reported for other peptidesof histidine [8-11,20,21] strongly support that the amino groups are the most basic sites of the peptides.

\subsection{Copper(II) complexes of the peptides}

The presence of a terminal amino group, an aspartyl and a histidyl residue offers the possibility of two well separated metal binding sites in both peptides. The N-terminus can be regarded as a tetrapeptide where the $\beta$-carboxylate group can also be involved in the metal ion coordination, while the internal histidine residue can behave as an anchoring sitefor the binding of another metal ion via the coordination of deprotonated amide nitrogens.

\section{Copper(II) complexes of $\mathrm{NH}_{2}-\mathrm{AADAAH}-\mathrm{NH}_{2}$}

In agreement with the above mentioned expectation the peptideNH $\mathrm{N}_{2}-\mathrm{AADAAH}-\mathrm{NH}_{2} \mathrm{can}$ effectively bind two equivalents of copper(II) ions as it is demonstrated by Figure 1.

Similarly to the common oligopeptides, $\left(\mathrm{NH}_{2}, \mathrm{CO}\right)$-coordinated $[\mathrm{CuHL}]^{2+}$ species with protonated imidazole groups are formed in small amounts in the acidic $\mathrm{pH}$ range. Taking into account the $\mathrm{pK}$ value of the histidyl moiety $\log \mathrm{K}=6.17$ can be calculated for the $\mathrm{Cu}(\mathrm{II})+\mathrm{HL}$ 
$=\mathrm{CuHL}$ reaction. This value is indicatively higher than those of the simple $\left(\mathrm{NH}_{2}, \mathrm{CO}\right)-$ coordinated copper(II)-peptide complexes $[3,4]$ supporting the stabilization by the $\beta$ carboxylate group of the aspartyl residue.

The species $[\mathrm{CuL}]^{+}$cannot be detected in measurable concentrationsuggesting that the deprotonation of two functional groups takes place in one step resulting in the formation of the $\left[\mathrm{CuH}_{-1} \mathrm{~L}\right]$ species. With this stoichiometry, two isomers can be supposed. The deprotonation of the first two amide functions may occur in a cooperative process generatingthe $\left(\mathrm{NH}_{2}, \mathrm{~N}^{-}, \mathrm{N}^{-}, \beta-\mathrm{COO}^{-}\right)$-coordinated $\left[\mathrm{CuH}_{-1} \mathrm{~L}\right]$ complex (its actual stoichiometry is $\left.\left[\mathrm{CuH}_{2} \mathrm{~L}(\mathrm{H})\right]\right)$ in which the imidazole nitrogen is still protonated. On the other hand, the deprotonation of the first amide and imidazole nitrogen cannot be excludedhence the cooperative formationof an $\left(\mathrm{NH}_{2}, \mathrm{~N}^{-}\right)$-coordinated $\left[\mathrm{CuH}_{-1} \mathrm{~L}\right]$ species supplemented by the coordination of the imidazole nitrogen, constructing a macrochelate structure. For the first isomer the deprotonation of $\left[\mathrm{CuH}_{-1} \mathrm{~L}\right]$ or the deprotonation of the uncoordinated imidazolium group cannot be accompanied with any change in the $\mathrm{CD}$ spectra. $\mathrm{pH}$-dependent $\mathrm{CD}$ spectra, however, reveal that saturation of $\mathrm{CD}$ extrema is obtained only by $\mathrm{pH} 8$ supporting the coexistence of the two isomers with a slight preference for the $\left(\mathrm{NH}_{2}, \mathrm{~N}^{-}, \mathrm{N}^{-}, \beta-\mathrm{COO}^{-}\right)$ coordination mode. By increasing $\mathrm{pH}\left[\mathrm{CuH}_{-2} \mathrm{~L}\right]^{-}$species is formed, which is an exclusive complex in the $\mathrm{pH}$ range 8 to 10 . The $\left(\mathrm{NH}_{2}, \mathrm{~N}^{-}, \mathrm{N}^{-}, \beta-\mathrm{COO}^{-}\right)$coordination mode of this species is supported by many factors; its UV-Vis, CD and EPR parameters are in good agreement with the literature data reported on the $\left[\mathrm{CuH}_{-2} \mathrm{~L}\right]^{4-}$ species of $\mathrm{Asp}_{3}$ andAsp $\mathrm{A}_{4}$ or related peptides [15]. In principle, the same stoichiometric composition can be assumed for the formation of $\left(\mathrm{N}^{-}, \mathrm{N}^{-}, \mathrm{N}_{\mathrm{im}}\right)$-coordinated isomers, too. The metal binding ability of these two coordination modes are comparedin Figure 2. In this model, the two metal binding sites are mimicked by the copper(II)- $\mathrm{NH}_{2}$-AADA-Ac-GGGH ternary system. The distribution curves indicates that in the $\mathrm{pH}$ range where the $\left[\mathrm{CuH}_{-2} \mathrm{~L}\right]^{-}$species is formed, solely the $\left(\mathrm{NH}_{2}, \mathrm{~N}^{-}, \mathrm{N}^{-}, \beta-\mathrm{COO}^{-}\right)$coordinated complex is present and the contribution of the $\left(\mathrm{N}^{-}, \mathrm{N}^{-}, \mathrm{N}_{\text {im }}\right)$ coordination mode is practically negligible.

Figure 1

Figure 2

A further increase in $\mathrm{pH}$ results in an additional base-consuming process and the concomitant blue-shift in the absorption and CD spectra. Interestingly, in contrast to other peptides containingaspartyl residue in third position, the formation of $\left[\mathrm{CuH}_{-3} \mathrm{~L}\right]^{2-}$ species is proved.For the CD spectrum of this complex,we founda good agreement with the spectra of the corresponding complex of $\mathrm{Ala}_{4}$, however,it is totally different from that of complexes containing $\left(\mathrm{N}^{-}, \mathrm{N}^{-}, \mathrm{N}^{-}, \mathrm{N}_{\text {im }}\right)$ coordination mode. As a consequence, the simple oligoglycine-like $\left(\mathrm{NH}_{2}, \mathrm{~N}^{-}, \mathrm{N}^{-}, \mathrm{N}^{-}\right)$coordination mode can be suggested in the highly basic solution. The $\mathrm{pK}$ value for the deprotonation of the third amide nitrogen is, however, 11.67 being more than two orders of magnitude higher than that of tetraglycine [23].

Figure 1 and Table 1 reveal that dinuclear complexes can also be formed in the presence of excess copper(II) ions. $\left[\mathrm{Cu}_{2} \mathrm{H}_{-1} \mathrm{~L}\right]^{2+}$ and $\left[\mathrm{Cu}_{2} \mathrm{H}_{-2} \mathrm{~L}\right]^{+}$are only minor species supporting that the second copper(II) ion is monodentately coordinated at the histidyl residue and the $\mathrm{N}$-terminus of the ligand is the main binding site as in the mononuclear complexes. The CD spectra of the $\left[\mathrm{Cu}_{2} \mathrm{H}_{4} \mathrm{~L}\right]^{-}$species can be fitted with the superposition of the spectra of 
a $\left(\mathrm{NH}_{2}, \mathrm{~N}^{-}, \mathrm{N}^{-}, \beta-\mathrm{COO}^{-}\right)$-coordinated and a $\left(\mathrm{N}^{-}, \mathrm{N}^{-}, \mathrm{N}_{\text {im }}\right)$-coordinated complex(i.e. $\left[\mathrm{CuH}_{2} \mathrm{~L}\right]^{-}$ species of this ligand and $\left[\mathrm{CuH}_{-1} \mathrm{~L}\right]^{+}$species of Ac-FKHV-NH $\left.\mathrm{N}_{2}[24]\right)$. The $\left(\mathrm{NH}_{2}, \mathrm{~N}^{-}, \mathrm{N}^{-}, \beta-\right.$ $\left.\mathrm{COO}^{-}\right)$coordination of one copper(II) ion and $\left(\mathrm{N}^{-}, \mathrm{N}^{-}, \mathrm{N}^{-}, \operatorname{Im}(\mathrm{N})\right)$ coordination of another copper(II) ion(see Scheme 1) can be confirmed in the $\left[\mathrm{Cu}_{2} \mathrm{H}_{5} \mathrm{~L}\right]^{2-}$ species by similar summationof the CD spectra.

Scheme 1

\section{Copper(II) complexes of $\mathrm{NH}_{2}-\mathrm{ADAAAH}-\mathrm{NH}_{2}$}

The metal ion speciation of the equimolar systems is depicted in Figure 3 indicating the formation of three major species. $[\mathrm{CuL}]^{+}$forms in a relatively high concentration around $\mathrm{pH} 5$ but with a significant overlapwith $\left[\mathrm{CuH}_{-1} \mathrm{~L}\right]$. Concerning common peptides, $\left(\mathrm{NH}_{2}, \mathrm{CO}\right)$ donor atoms are typically coordinated in ML species. In the case of $\mathrm{NH}_{2}-\mathrm{ADAAAH}-\mathrm{NH}_{2}$, the appearance of this donor set completed by the binding of the imidazole group cannot be ruled out. On the other hand, there is the opportunity for the formation of another isomer with $\left[\mathrm{CuH}_{-1} \mathrm{~L}(\mathrm{H})\right]^{+}$stoichiometry in which the amino terminus is tridentately coordinated $\left(\left(\mathrm{NH}_{2}, \mathrm{~N}^{-}\right.\right.$ ,$\beta-\mathrm{COO}^{-}$) coordination) while the imidazole nitrogen is still protonated. The EPR spectra undoubtedly prove the existence of both isomers. UV-visible and CD spectra provide further support for this assumption. The low intensity of CD extrema rules out the quantitative determination of the ratio of these isomers, but $\mathrm{CD}$ and absorption maxima values support the preference for the formation of the amide bonded species.

Figure 3

The species $\left[\mathrm{CuH}_{-1} \mathrm{~L}\right]$ is the solely complex formed in the $\mathrm{pH}$ range 7 to 9 . Its remarkable stability (which is one order of magnitude higher than those of $\mathrm{Cu}(\mathrm{II})$-complexes of peptides containing a single aspartic acid in the second position) is due to the formation of a macrochelatewith the involvement of the imidazole nitrogen atom besides the $\left(\mathrm{NH}_{2}, \mathrm{~N}^{-}, \beta\right.$ $\mathrm{COO}^{-}$) coordination.For this reason, its spectral parameters are significantly distinct from that of other peptides containingaspartic acid at the second position [15].The deprotonation of the second and third amide functions is a cooperative process resulting the species $\left[\mathrm{CuH}_{-3} \mathrm{~L}\right]^{2-}$ .The spectral parameters of this complex slightly differfrom that of $\left(\mathrm{NH}_{2}, \mathrm{~N}^{-}, \mathrm{N}^{-}, \mathrm{N}^{-}\right)$coordinated complexes. The blue shift of the absorption maxima of the complex and the $\mathrm{CD}$ spectral parameters suggest the presence of the $\left(\mathrm{N}^{-}, \mathrm{N}^{-}, \mathrm{N}^{-}, \mathrm{N}_{\text {im }}\right)$-coordinated isomer species in about $30 \%$ besides to the above mentioned isomer. The same ratio of the two coordination modes can be seen above $\mathrm{pH} 11$ in the copper(II)- $\mathrm{NH}_{2}$-ADAA-Ac-GGGH ternary model system.

As it was mentioned earlier, there is the possibility of formation of dinuclear copper(II) species with this ligand, too. Nevertheless, the results of this study challenged this expectation. The lack of dinuclear species can be explained by the increased stability of the neutral $\left[\mathrm{CuH}_{-1} \mathrm{~L}\right]$ complex. The coordination of the second copper(II) ion would require the binding of histidine residue, it is however, involved in the binding of the first copper(II) ion.As a result, the excess of copper(II) ions precipitates fromthe solution around $\mathrm{pH} 6$ which redissolves only in strongly alkaline media. This suggests the coordination of each amide nitrogen donor atom with $\left[\mathrm{Cu}_{2} \mathrm{H}_{-5} \mathrm{~L}\right]^{2-}$ stoichiometry in which $\left(\mathrm{NH}_{2}, \mathrm{~N}^{-}, \mathrm{N}^{-}\right)\left(\mathrm{N}^{-}, \mathrm{N}^{-}, \mathrm{N}^{-}, \mathrm{N}_{\text {im }}\right)$ and 
$\left(\mathrm{NH}_{2}, \mathrm{~N}^{-}, \mathrm{N}^{-}, \mathrm{N}^{-}\right)\left(\mathrm{N}^{-}, \mathrm{N}^{-}, \mathrm{N}_{\mathrm{im}}\right)$ coordination modes can coexist. Comparison of the CD spectra of 2:1 copper(II)- $\mathrm{NH}_{2}$-ADAAAH- $\mathrm{NH}_{2}$ sample recorded at $\mathrm{pH} 11.7$ with those of model compounds strongly supports this assumption. Figure 4 is used to demonstrate this comparison applying tetraalanine [15] and Ac-FKHV-NH $\mathrm{N}_{2}$ as model compounds. The positive Cotton effect around $650 \mathrm{~nm}$ and negative band around $345 \mathrm{~nm}$ are the best indication for simultaneous formation of all coordination modes, while the best fit of the measured and calculated spectra was obtained when the isomers are present in the same ratio.

Figure 4

The results obtained for the copper(II) complexes of $\mathrm{NH}_{2}-\mathrm{AADAAH}-\mathrm{NH}_{2}$ and $\mathrm{NH}_{2}$ ADAAAH-NH $\mathrm{N}_{2}$ strongly support that both peptides are effective complexing agents. Their metal binding ability is, however, greatly $\mathrm{pH}$-dependent as it is most vividly represented by Figure 5. The metal ion speciation of a model system is shown in this Figure containing the metal ion and the two peptides in equimolar concentration. The thin solid lines demonstrate the molar ratios of the various species, while the thick dotted lines represent the total amount of copper(II) bonded to the corresponding peptides. It is evident from this Figure that $\mathrm{NH}_{2}-$ ADAAAH- $\mathrm{NH}_{2}$ forms the more stable complexes in slightly acidic samples while the $\left(\mathrm{NH}_{2}, \mathrm{~N}^{-}, \mathrm{N}^{-}, \beta-\mathrm{COO}^{-}\right)$coordinated species of $\mathrm{NH}_{2}-\mathrm{AADAAH}-\mathrm{NH}_{2}$ will predominate in alkaline solution. This behavior reflects on the difference in the major coordination modes of the two peptides, the $\left(\mathrm{NH}_{2}, \mathrm{~N}^{-}, \beta-\mathrm{COO}^{-}, \mathrm{N}_{\text {im }}\right)$ macrochelate, and the $(5,5,6)$-membered fused chelates for $\mathrm{NH}_{2}-\mathrm{ADAAAH}-\mathrm{NH}_{2}$ and $\mathrm{NH}_{2}-\mathrm{AADAAH}-\mathrm{NH}_{2}$, respectively. The intersection of the curves is in the range of the physiological $\mathrm{pH}$ values indicating that both peptides can effectively contribute to the binding of copper(II) in biological systems.

Figure 5

\subsection{Nickel(II) complexes of the peptides Nickel(II) complexes of $\mathrm{NH}_{2}-\mathrm{AADAAH}-\mathrm{NH}_{2}$}

The stoichiometry of the complexes formed in the nickel(II)- $\mathrm{NH}_{2}-\mathrm{AADAAH}-\mathrm{NH}_{2}$ system (see Table 1) is similar to those of copper(II) but the formation of all nickel(II) containing species is shifted to a more alkaline $\mathrm{pH}$ range. The complexation of nickel(II) begins around $\mathrm{pH} 5$ with $\left(\mathrm{NH}_{2}, \mathrm{CO}\right)$-coordinated $[\mathrm{NiHL}]^{2+}$ species. The imidazole group must be protonated in thiscomplex, though its subsequent coordination increases the stability of the $[\mathrm{NiL}]^{+}$species besides the same effect of the $\beta$-carboxylate group. The UV-visible spectra undoubtly prove that they are octahedral complexes. However, the formation of the $\left[\mathrm{NiH}_{2} \mathrm{~L}\right]^{-}$species is accompanied by some significant changes in the visible absorption and CD spectra, indicating the square planar geometry of these nickel(II) complexes (Table 2). Similarly to the copper(II) complexes, the formation of two isomers is possible with $\left[\mathrm{NiH}_{-2} \mathrm{~L}\right]^{-}$stoichiometry, $\mathrm{i}$. e. $\left(\mathrm{NH}_{2}, \mathrm{~N}^{-}, \mathrm{N}^{-}, \beta-\mathrm{COO}^{-}\right)$and $\left(\mathrm{N}^{-}, \mathrm{N}^{-}, \operatorname{Im}(\mathrm{N})\right)$ coordinated complexes. The spectral parameters of this species agree well with those of the $\mathrm{Ni}(\mathrm{II})$-complexes of $\mathrm{Asp}_{3}$ and $\mathrm{Asp}_{4}[16]$, therefore the formation of the former coordination mode is highly preferred. $\left[\mathrm{NiH}_{-3} \mathrm{~L}\right]^{2-}$ is the exclusivespecies above $\mathrm{pH} 11$ and the characteristics and intensity of its $\mathrm{CD}$ spectrumare similar to those of $\left(\mathrm{NH}_{2}, \mathrm{~N}^{-}, \mathrm{N}^{-}, \mathrm{N}^{-}\right)$coordinated $\left[\mathrm{NiH}_{-3} \mathrm{~L}\right]^{2-}$ complex of Ala 4 . At the same time, the appearance of a shoulder around $420 \mathrm{~nm}$ may refer to the presence of the $\left(\mathrm{N}^{-}, \mathrm{N}^{-}, \mathrm{N}^{-}\right.$ , $\operatorname{Im}(\mathrm{N})$ ) coordination mode in low concentration. 


\section{Nickel(II) complexes of $\mathrm{NH}_{2}-\mathrm{ADAAAH}-\mathrm{NH}_{2}$}

Both the coordination modes and the stoichiometry of the major nickel(II) complexes of the two peptides deviate from each other. The complexation starts with the formation of $\left(\mathrm{NH}_{2}, \mathrm{CO}\right)$ coordinated octahedral $[\mathrm{NiL}]^{+}$species, in which the coordination of the imidazole nitrogen and/or the $\beta$-carboxylate group may increase the stability of the complex. The $\log \beta$ value [25] of the corresponding $\mathrm{Gly}_{4}$ speciesis 3.65, which is one order of magnitude lower than that of the complex of our peptide. Unlikethe copper(II) containing system, other isomer of the ML complex does not form, since the lack of CD extrema below $\mathrm{pH} 7.5$ rules out the deprotonation of the amide groups, while the imidazole is protonated. The increase of $\mathrm{pH}$ to 7.5 to 8.0 results in precipitation which is probably a neutral mixed hydroxo complex. The formation of $\left[\mathrm{NiL}_{2}\right]$ bis(ligand) complexes in the presence of excess of ligand, however, prevents precipitation and provides a chance for the computer evaluation of potentiometric data in alkaline media. The ratio of the stepwise stability constants $\log \left(\mathrm{K}_{1} / \mathrm{K}_{2}\right)=0.90$ supports that both $[\mathrm{NiL}]^{+}$and $\left[\mathrm{NiL}_{2}\right]$ are octahedral species containing bi- and/or tri-dentately coordinated ligands. The coordination of deprotonated amide nitrogens starts above $\mathrm{pH} 8.0$ with the concomitant development of $\mathrm{CD}$ extrema and characteristic yellow colour of the samples. This observation strongly support the presence of square planar nickel(II) ions in the species $\left[\mathrm{NiH}_{-2} \mathrm{~L}\right]^{-}$and $\left[\mathrm{NiH}_{-3} \mathrm{~L}\right]^{2-}$. The spectral parameters of the latter species can be easily calculated and are virtually identical with those of $\mathrm{NH}_{2}-\mathrm{AADAAH}-\mathrm{NH}_{2}$. As a consequence, the formation of $\left(\mathrm{NH}_{2}, \mathrm{~N}^{-}, \mathrm{N}^{-}, \mathrm{N}^{-}\right)$and $\left(\mathrm{N}^{-}, \mathrm{N}^{-}, \mathrm{N}^{-}, \operatorname{Im}(\mathrm{N})\right)$ coordinated isomers can also be proposed where the estimated amount of the latter isomer is not higher than $10 \%$.

The major difference in the complex formation processes of nickel(II) and copper(II) with the two peptidesis the lack of stable and water soluble dinuclear complexes. The solely calculated dinuclear species is $\left[\mathrm{Ni}_{2} \mathrm{H}_{-2} \mathrm{~L}\right]^{+}$of $\mathrm{NH}_{2}-\mathrm{AADAAH}-\mathrm{NH}_{2}$, in which one nickel(II) ion is coordinated on the $\mathrm{N}$-terminus via $\left(\mathrm{NH}_{2}, \mathrm{~N}^{-}, \mathrm{N}^{-}, \beta-\mathrm{COO}^{-}\right)$donor atoms while the second nickel(II) ion is monodentately bounded to the histidyl residue as supported by the corresponding UV-vis and CD spectra. This binding mode, however, cannot prevent the precipitation of nickel(II)-hydroxide by further increase of $\mathrm{pH}$. The precipitation prevents the equilibrium analysis of the $2: 1$ systems, but the presence of dinuclear species were found by spectroscopic methods above $\mathrm{pH} 11.0$.

\subsection{Zinc(II) complexes of the peptides}

It is obvious from Table 1 that the metal ion speciation of the zinc(II)-peptide systems are quite simple and akin with each other. The $[\mathrm{ZnL}]^{+}$complexes are the major species in both system, forming around the physiological $\mathrm{pH}$ range. Their stability constants are higher [26] than those of the $\mathrm{Zn}$ (II)-complexes of common peptides, and similar to those of complexes of peptides containing several donor functionsindicating the existence of macrochelates with the involvement of the $\beta$-carboxylate and/or imidazole donor groups. The stability of these species arealso close to that of the corresponding ML species of the nickel(II) ion. However, this coordination mode is neither able to prevent the hydrolysis of the zinc(II) ions nor promote the ionization and metal binding to amide functions.(Note that the $\log \beta$ of $\mathrm{ZnL}$ of $\mathrm{NH}_{2}$-ADAAAH- $\mathrm{NH}_{2}$ - is greater to some extent and the precipitation takes place at a higher 
$\mathrm{pH}$ when compared to $\mathrm{NH}_{2}-\mathrm{AADAAH}-\mathrm{NH}_{2}$. It could be explained by the fact that the stability increasing aspartyl residue in the second position is nearerto the bounded $\mathrm{Zn}$ (II) ion.)Bothspecies $\left[\mathrm{ZnH}_{-1} \mathrm{~L}\right]$ and $\left[\mathrm{ZnH}_{-2} \mathrm{~L}\right]^{-}$formed above $\mathrm{pH} 8$ are probably mixed hydroxo complexes.

\subsection{Mixed metal complexes of the peptides}

The presence of dinuclear complexes in the copper(II) and the high $\mathrm{pH}$ nickel(II) containing systems provides the opportunity for the formation of mixed metal species. The interactions with all three combinations of the metal ions were studied in equimolar samples of two different metal ions and one of the peptides by $\mathrm{pH}$ potentiometric and spectroscopic methods.Precipitation was observed around the physiological $\mathrm{pH}$ range in all systems, therefore stability constants were notcalculated.

Both UV-visible and CD spectra of the copper(II)-zinc(II)- and nickel(II)-zinc(II)peptide samples exhibit virtually complete agreement with those of the corresponding copper(II) or nickel(II) binarysolutionsat all $\mathrm{pH}$ values, respectively. This suggests that both copper(II) and nickel(II) ions have the same metal binding affinity in the ternary systems as they have in the binary ones. As a consequence, zinc(II) cannot replace copper(II) or nickel(II), but it can occupy the free binding sites of the peptides.

Interestingly, the emerge of mixed metal complexes has been proved in the copper(II)nickel(II)-hexapeptide systems. There was also a slight precipitation in these systems preventing the determination of stability constants. These precipitates were, however, dissolved by high $\mathrm{pH}$ providing the opportunity for the quantitative evaluation of the spectra recorded in the mixed metal systems. It is clear from the UV-visible and CD spectra that only copper(II) ions are bounded to the peptides below $\mathrm{pH}$ 7.0. The characteristic changes of these spectra by increasing the $\mathrm{pH}$, however, convincingly demonstrate the binding of nickel(II) which could take place to the ligands or to the copper(II) containing species. The CD spectra of the mixed metal and of the binary systems above $\mathrm{pH} 11$ are shown on Figure 6 . It can be seen that the CD spectra of the copper(II)-nickel(II)- $\mathrm{NH}_{2}-\mathrm{AADAAH}-\mathrm{NH}_{2}$ ternary system practically agree with the sum of the binary systems at 2:1 metal to ligand ratios. It means that although both metal ions have a preference for binding at the N-terminus, and copper(II) ions have higher binding affinity, it is the nickel(II) ions that are able to alter the distribution of copper(II) ions. As a result,both metal ions are coordinated statistically among the $\mathrm{N}$ - and Ctermini of the peptides.

Figure 6

\section{Conclusions}

Both potentiometric and spectroscopic data support that the peptides $\mathrm{NH}_{2}-\mathrm{AADAAH}-\mathrm{NH}_{2}$ and $\mathrm{NH}_{2}$-ADAAAH- $\mathrm{NH}_{2}$ contain two well separated metal binding sites. The amino terminus is the anchoring site of both ligands for the complexation with all three metal ions, copper(II), nickel(II) and zinc(II). The metal binding of the $\beta$-carboxylate function of the second or third aspartyl residue enhances the thermodynamic stability of the complexes and shifts the deprotonation of the subsequent amide functions into a more alkaline $\mathrm{pH}$ range. In the case of $\mathrm{NH}_{2}$-AADAAH-NH $\mathrm{H}_{2}$ the imidazole- $\mathrm{N}$ donor of histidyl residue does not have a significant contribution to the overall stability of the $\left[\mathrm{MH}_{-2} \mathrm{~L}\right]^{-}$complex, which is one of the major 
species in equimolar samples. On the other hand, the side chain imidazole can be an independent metal binding site resulting in the formation of dinuclear or even mixed metal complexes containing copper(II) and/or nickel(II) ions. These species are especially important for copper(II) and formed by physiological $\mathrm{pH}$, while the corresponding nickel(II) species are present only in strongly basic solutions. The stabilizing role of the histidyl residue is much more pronounced in the complexes of $\mathrm{NH}_{2}-\mathrm{ADAAAH}-\mathrm{NH}_{2}$ peptide.In this case a tridentate $\left(\mathrm{NH}_{2}, \mathrm{~N}^{-}, \beta-\mathrm{COO}^{-}\right)$-coordination can be formed first and its stability can be significantly enhanced by the macrochelation of the side chain imidazole. The formation of this macrochelate, however, does not exclude the anchoring role of the imidazole at high $\mathrm{pH}$ and it can result in the existence of coordination isomers of the $\left[\mathrm{MH}_{-3} \mathrm{~L}\right]^{2-}$ complexes or the formation of dinuclear complexes. The coordination chemistry of the corresponding zinc(II) complexes is rather different from those of copper(II) and nickel(II). Zinc(II) ions are not able to induce deprotonation and coordination of amide groups in any cases. Nevertheless, the presence of two anchoring sites (terminal amino and side chain imidazole) in one molecule increase the stability of the corresponding zinc(II) complexes as compared to those of oligoglycines.

\section{Acknowledgements}

This research was supported by the European Union and the State of Hungary, co-financed by the European Social Fund in the framework of TÁMOP 4.2.4. A/1-11-1-2012-0001 'National Excellence Program' and the project ENVIKUT (TÁMOP-4.2.2.A-11/1/KONV-2012-0043). 
References

[1] G. Arena, D. La Mendola, G. Pappalardo, I. Sóvágó, E. Rizzarelli, Coord. Chem. Rev., (2012) 256, 2202-2218.

[2] G. Arena, G. Pappalardo, I. Sóvágó, E. Rizzarelli, Coord. Chem. Rev., (2012) 256, 312.

[3] H. Sigel, R.B. Martin, Chem. Rev., (1982) 82, 385-426.

[4] I. Sóvágó, C. Kállay, K. Várnagy, Coord. Chem. Rev., (2012) 256, 2225-2233.

[5] H. Kozlowski, W. Bal, M. Dyba, T. Kowalik-Jankowska, Cord. Chem. Rev., (1999) 184, 319-346.

[6] I. Sóvágó, K. Ösz, Dalton Trans., (2006) 3841-3854.

[7] M. Kuczer, M. Pietruszka, T. Kowalik-Jankowska, J. Inorg. Biochem., (2012) 111, 4049.

[8] I. Turi, D. Sanna, E. Garribba, G. Pappalardo, I. Sóvágó, Polyhedron, (2013) 62, 7-17.

[9] Á. Grenács, A. Kaluha, C. Kállay, V. Jószai, D. Sanna, I. Sóvágó, J. Inorg. Biochem., (2013) 128, 17-25.

[10] C. Kállay, K. Ösz, A. Dávid, Z. Valastyán, G. Malandrinos, N. Hadjiliadis, I. Sóvágó, Dalton Trans., (2007) 4040-4047.

[11] Á. Grenács, I. Sóvágó, J. Inorg. Biochem., (2014) 139, 49-56.

[12] I. Sóvágó, T. Kiss, A. Gergely, Inorg. Chim Acta, (1984) 93, L53-L55.

[13] J.F. Galey, B. Decock-Le Reverend, A. Lebkiri, L.D. Pettit, S.I. Pyburn, H.

Kozlowski, J. Cham. Soc., Dalton Trans., (1991), 2281-2287.

[14] I. Sóvágó, C. Bertalan, L. Göbl, I. Schőn, O. Nyéki, J. Inorg. Biochem., (1994) 55, 6775.

[15] C. Kállay, K. Várnagy, G. Micera, D. Sanna, I. Sóvágó, J. Inorg. Biochem., (2005) 99, 1514-1525.

[16] C. Kállay, I. Sóvágó, K. Várnagy, Polyhedron, (2007) 26, 811-817.

[17] V. Jószai, I. Sóvágó, Polyhedron, (2011) 30, 2114-2120.

[18] H. Irving, G. Miles, L.D. Pettit, Anal. Chim. Acta, (1967) 38, 475.

[19] L. Zékány, I. Nagypál, in: D. Leggett (ed.) Computational Methods for the Determination of Stability Constants, Plenum Press, New York, 1985, p. 291.

[20] D. Árus, A. Jancsó, D. Szunyogh, F. Matyuska, N.V. Nagy, E. Hoffman, T. Körtvélyesi, T. Gajda, (2012) 106, 10-18.

[21] G.F. Bryce, R.W. Roeske, F.R.N. Gurd, J. Biol. Chem., 240, 3837 (1965)

[22] B. Decock, A. Lebkiri, C. Livera, L. Pettit, Inorg. Chim. Acta, 124, L19 (1986)

[23] I. Sóvágó, D. Sanna, A. Dessi, K. Várnagy, G. Micera, J. Inorg. Biochem.,63, 99-117 (1996)

[24] V. Jószai, Z. Nagy, K. Ősz, D. Sanna, G. Di Natale, D. La Mendola, G. Pappalardo, E. Rizzarelli, I. Sóvágó,J. Inorg. Biochem.,100, 1399 (2006)

[25] R.B. Martin, M. Chamberlin, J.T. Edsall, J. Am. Chem. Soc.,82, 495 (1960).

[26] D.L. Rabenstein, S. Libich, Inorg. Chem., 11, 2960 (1972) 


\section{Table 1}

$\mathrm{pK}$ values and stability constants $\left(\log \beta_{\mathrm{pqr}}\right)$ of the metal complexes of the hexapeptides $\mathrm{NH}_{2}$ AADAAH- $\mathrm{NH}_{2}$ and $\mathrm{NH}_{2}$-ADAAAH-NH ${ }_{2}\left(\mathrm{~T}=298 \mathrm{~K}, \mathrm{I}=0.2 \mathrm{~mol} / \mathrm{dm}^{3}, \mathrm{KCl}\right.$ standard deviations are in parenthesis)

\begin{tabular}{|l|c|c|c|c|c|c|}
\hline & \multicolumn{3}{|c|}{$\mathrm{NH}_{2}$-AADAAH-NH } & \multicolumn{3}{c|}{$\mathrm{NH}_{2}-\mathrm{ADAAAH}_{2}$} \\
\hline Species & $\mathrm{pK}$ & & & $\mathrm{pK}$ & & \\
\hline$[\mathrm{HL}]$ & $3.50(3)$ & & & $3.41(2)$ & & \\
\hline$\left[\mathrm{H}_{2} \mathrm{~L}\right]^{+}$ & $6.57(1)$ & & & $6.46(1)$ & & \\
\hline$\left[\mathrm{H}_{3} \mathrm{~L}\right]^{2+}$ & $8.05(1)$ & & & $8.06(1)$ & & \\
\hline & & & & & & \\
\hline & $\mathrm{Cu}(\mathrm{II})$ & $\mathrm{Ni}(\mathrm{II})$ & $\mathrm{Zn}(\mathrm{II})$ & $\mathrm{Cu}(\mathrm{II})$ & $\mathrm{Ni}(\mathrm{II})$ & $\mathrm{Zn}(\mathrm{II})$ \\
\hline$\left[\mathrm{MHL}^{2+}\right.$ & $12.74(2)$ & $10.88(5)$ & $10.72(5)$ & $12.15(18)$ & & $10.60(9)$ \\
\hline$\left[\mathrm{ML}^{+}\right.$ & - & $4.91(1)$ & $4.45(1)$ & $8.70(2)$ & $4.72(4)$ & $4.39(2)$ \\
\hline$\left[\mathrm{MH}_{-1} \mathrm{~L}\right]$ & $2.52(1)$ & - & $-4.05(5)$ & $3.71(2)$ & - & $-3.67(2)$ \\
\hline$\left[\mathrm{MH}_{2} \mathrm{~L}\right]^{-}$ & $-4.35(3)$ & $-10.43(1)$ & $-13.20(4)$ & & $-12.45(4)$ & $-12.55(3)$ \\
\hline$\left[\mathrm{MH}_{3} \mathrm{~L}\right]^{-}$ & $-16.02(4)$ & $-20.19(2)$ & - & $-16.65(2)$ & $-22.71(10)$ & - \\
\hline$\left[\mathrm{ML}_{2}\right]$ & - & - & - & - & $8.54(9)$ & - \\
\hline$\left[\mathrm{M}_{2} \mathrm{H}_{1} \mathrm{~L}\right]^{2+}$ & $5.12(4)$ & - & - & - & - & - \\
\hline$\left[\mathrm{M}_{2} \mathrm{H}_{2} \mathrm{~L}\right]^{+}$ & $-0.80(7)$ & $-7.57(4)$ & - & - & - & - \\
\hline$\left[\mathrm{M}_{2} \mathrm{H}_{4} \mathrm{~L}\right]^{-}$ & $-12.47(2)$ & - & - & - & - & - \\
\hline$\left[\mathrm{M}_{2} \mathrm{H}_{-5} \mathrm{~L}\right]^{2-}$ & $-22.52(3)$ & - & - & - & - & - \\
\hline
\end{tabular}


Table 2

Spectroscopic data of the major species of the studied ligands formed with copper(II)- and nickel(II) ions

\begin{tabular}{|c|c|c|c|c|c|c|}
\hline & \multicolumn{3}{|c|}{$\mathrm{NH}_{2}-\mathrm{AADAAH}-\mathrm{NH}_{2}$} & \multicolumn{3}{|c|}{$\mathrm{NH}_{2}$-ADAAAH-NH${ }_{2}$} \\
\hline Species & $\begin{array}{l}\lambda / \varepsilon(\mathrm{nm} / \\
\left.\mathrm{M}_{\mathrm{cm}}^{-1}\right)\end{array}$ & $\begin{array}{c}\lambda / \Delta \varepsilon(\mathrm{nm} / \\
\left.\mathrm{M}_{\mathrm{cm}}^{-1}\right)\end{array}$ & $\begin{array}{c}\mathrm{g} / \mathrm{A}_{\|}\left(10^{-4}\right. \\
\left.\mathrm{cm}^{-1}\right)\end{array}$ & $\begin{array}{l}\lambda / \varepsilon(\mathrm{nm} / \\
\left.\mathrm{M}^{-1} \mathrm{~cm}^{-1}\right)\end{array}$ & $\begin{array}{c}\lambda / \Delta \varepsilon(\mathrm{nm} / \\
\left.\mathrm{M}_{\mathrm{cm}}^{-1}\right)\end{array}$ & $\begin{array}{c}\mathrm{g} / \mathrm{A}_{\|} \\
\left(10^{-4} \mathrm{~cm}^{-1}\right)\end{array}$ \\
\hline$[\mathrm{CuHL}]^{2+}$ & $764(41)$ & - & & - & - & \\
\hline$[\mathrm{CuL}]^{+}$ & - & - & & $637(79)$ & $\begin{array}{l}300(-1.23) \\
604(+0.17)\end{array}$ & $\begin{array}{l}2.328 / 154.5^{\mathrm{a}} \\
2.247 / 189.6^{\mathrm{b}}\end{array}$ \\
\hline$\left[\mathrm{CuH}_{1} \mathrm{~L}\right]$ & $565(103)$ & $\begin{array}{c}590(-0.51) \\
495(+0.15) \\
310(+0.63)\end{array}$ & $2.227 / 167.1$ & $610(105)$ & $\begin{array}{l}303(-1.09) \\
499(+0.06) \\
586(-0.16) \\
693(+0.09)\end{array}$ & $2.234 / 181.9$ \\
\hline$\left[\mathrm{CuH}_{-2} \mathrm{~L}\right]^{-}$ & $549(149)$ & $\begin{array}{l}590(-0.55) \\
494(+0.30) \\
310(+0.58)\end{array}$ & $2.206 / 207.3$ & - & - & - \\
\hline$\left[\mathrm{CuH}_{3} \mathrm{~L}\right]^{2-}$ & $527(147)$ & $\begin{array}{l}532(-1.00) \\
308(+0.83)\end{array}$ & $2.175 / 206.1$ & $519(147)$ & $\begin{array}{l}308(+0.81) \\
525(-1.17) \\
656(+0.18)\end{array}$ & $2.185 / 201.9$ \\
\hline$\left[\mathrm{Cu}_{2} \mathrm{H}_{-4} \mathrm{~L}\right]^{-}$ & $555(108)$ & $\begin{array}{l}613(-0.15) \\
527(+0.36) \\
336(-0.55)\end{array}$ & - & - & - & - \\
\hline $\begin{array}{l}{\left[\mathrm{Cu}_{2} \mathrm{H}\right.} \\
\left.{ }_{5} \mathrm{~L}\right]^{2-}\end{array}$ & $539(128)$ & $\begin{array}{c}668(+0.17) \\
558(-0.49) \text { broad } \\
\text { shoulder } \\
341(-0.30) \\
303(+0.45)\end{array}$ & - & - & - & - \\
\hline$\left[\mathrm{NiH}_{2} \mathrm{~L}\right]^{-}$ & $438(238)$ & $\begin{array}{c}493(-2.07) \\
425(1.41) \\
\end{array}$ & - & - & - & - \\
\hline$\left[\mathrm{NiH}_{-3} \mathrm{~L}\right]^{2-}$ & $413(219)$ & $\begin{array}{c}467(-3.01) \\
417(-2.22)^{\text {shoulder }}\end{array}$ & - & $412(225)$ & $\begin{array}{c}470(-3.12) \\
414(-2.11)^{\text {shoulder }}\end{array}$ & - \\
\hline
\end{tabular}

${ }^{\mathrm{a}}\left(\mathrm{NH}_{2}, \mathrm{CO}\right) \operatorname{Im}(\mathrm{N})$-coordinated isomer

${ }^{\mathrm{b}}\left(\mathrm{NH}_{2}, \mathrm{~N}^{-}, \beta-\mathrm{COO}^{-}\right)$-coordinated isomer 


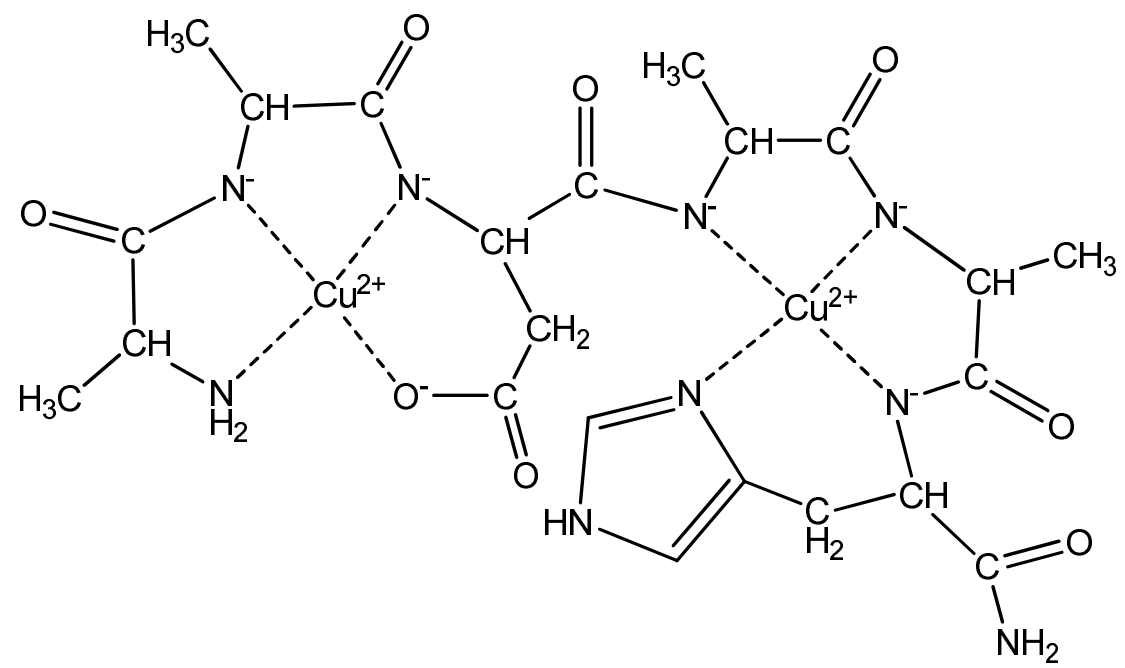

Scheme 1 


\section{Legends to Figures}

\section{Figure 1}

Concentration distribution of the complexes formed in the copper(II)- $\mathrm{NH}_{2}-\mathrm{AADAAH}-\mathrm{NH}_{2}$ system (a) $\mathrm{c}_{\mathrm{Cu}(\mathrm{II})}=\mathrm{c}_{\mathrm{L}}=2 \mathrm{mM}$ and (b) $\mathrm{c}_{\mathrm{Cu} \text { (II) }}=4 \mathrm{mM}, \mathrm{c}_{\mathrm{L}}=2 \mathrm{mM}$.

\section{Figure 2}

Distribution of copper(II) ions between AADA (A) and Ac-GGGH (B) as a function of $\mathrm{pH}$ $\left(\mathrm{c}_{\mathrm{Cu}(\mathrm{II})}=\mathrm{c}_{\mathrm{A}}=\mathrm{c}_{\mathrm{B}}=2 \mathrm{mM}\right)$. (Stability constants are taken from Refs. 21., 22.)

\section{Figure 3}

Metal ion speciation of the copper(II)- $\mathrm{NH}_{2}-\mathrm{ADAAAH}-\mathrm{NH}_{2}$ system at 1:1 metal to ligand ratio $\left(\mathrm{c}_{\mathrm{Cu}(\mathrm{II})}=\mathrm{c}_{\mathrm{L}}=2 \mathrm{mM}\right)$

\section{Figure 4}

(a) Measured and (b) calculated CD spectra of the $\left[\mathrm{Cu}_{2} \mathrm{H}_{-5} \mathrm{~L}\right]^{2-}$ complex using the CD spectra of model systems: (c) $\left[\mathrm{CuH}_{-3} \mathrm{~L}\right]^{2-}$ species of $\mathrm{Ala}_{4}\left(\left(\mathrm{NH}_{2}, \mathrm{~N}^{-}, \mathrm{N}^{-}, \mathrm{N}^{-}\right)\right.$coordination), (d) $\left[\mathrm{CuH}_{-}\right.$ $\left.{ }_{2} \mathrm{~L}\right]^{-}$species of $\mathrm{Ala}_{4}\left(\left(\mathrm{NH}_{2}, \mathrm{~N}^{-}, \mathrm{N}^{-}\right)\right.$coordination $),(\mathrm{e})\left[\mathrm{CuH}_{2} \mathrm{~L}\right]$ species of Ac-FKHV-NH $\mathrm{N}_{2}\left(\left(\mathrm{~N}^{-}\right.\right.$ $\left., \mathrm{N}^{-}, \mathrm{N}^{-}, \operatorname{Im}(\mathrm{N})\right)$ coordination) and (f) $\left[\mathrm{CuH}_{-1} \mathrm{~L}\right]^{+}$species of Ac-FKHV-NH${ }_{2}\left(\left(\mathrm{~N}^{-}, \mathrm{N}^{-}, \operatorname{Im}(\mathrm{N})\right)\right.$ coordination)

\section{Figure 5}

Distribution of copper(II) ions between $\mathrm{NH}_{2}-\mathrm{AADAAH}-\mathrm{NH}_{2}(\mathrm{~A})$ and $\mathrm{NH}_{2}-\mathrm{ADAAAH}-\mathrm{NH}_{2}$ (B) as a function of $\mathrm{pH}\left(\mathrm{c}_{\mathrm{Cu}(\mathrm{II})}=\mathrm{c}_{\mathrm{A}}=\mathrm{c}_{\mathrm{B}}=1 \mathrm{mM}\right)$.

\section{Figure 6}

CD spectra of the high $\mathrm{pH}$ samples recorded (a) at 2:1 ratio in the copper(II)- $\mathrm{NH}_{2}$ AADAAAH-NH $\mathrm{N}_{2}$ system,(b) at2:1 ratio in the nickel(II)- $\mathrm{NH}_{2}-\mathrm{AADAAAH}-\mathrm{NH}_{2}$ system,(c)at 1:1:1 ratio in the copper(II)-nickel(II)- $\mathrm{NH}_{2}-\mathrm{AADAAAH}-\mathrm{NH}_{2}$ system. Spectrum (d) is calculated by the superposition of spectra (a) and (b). 

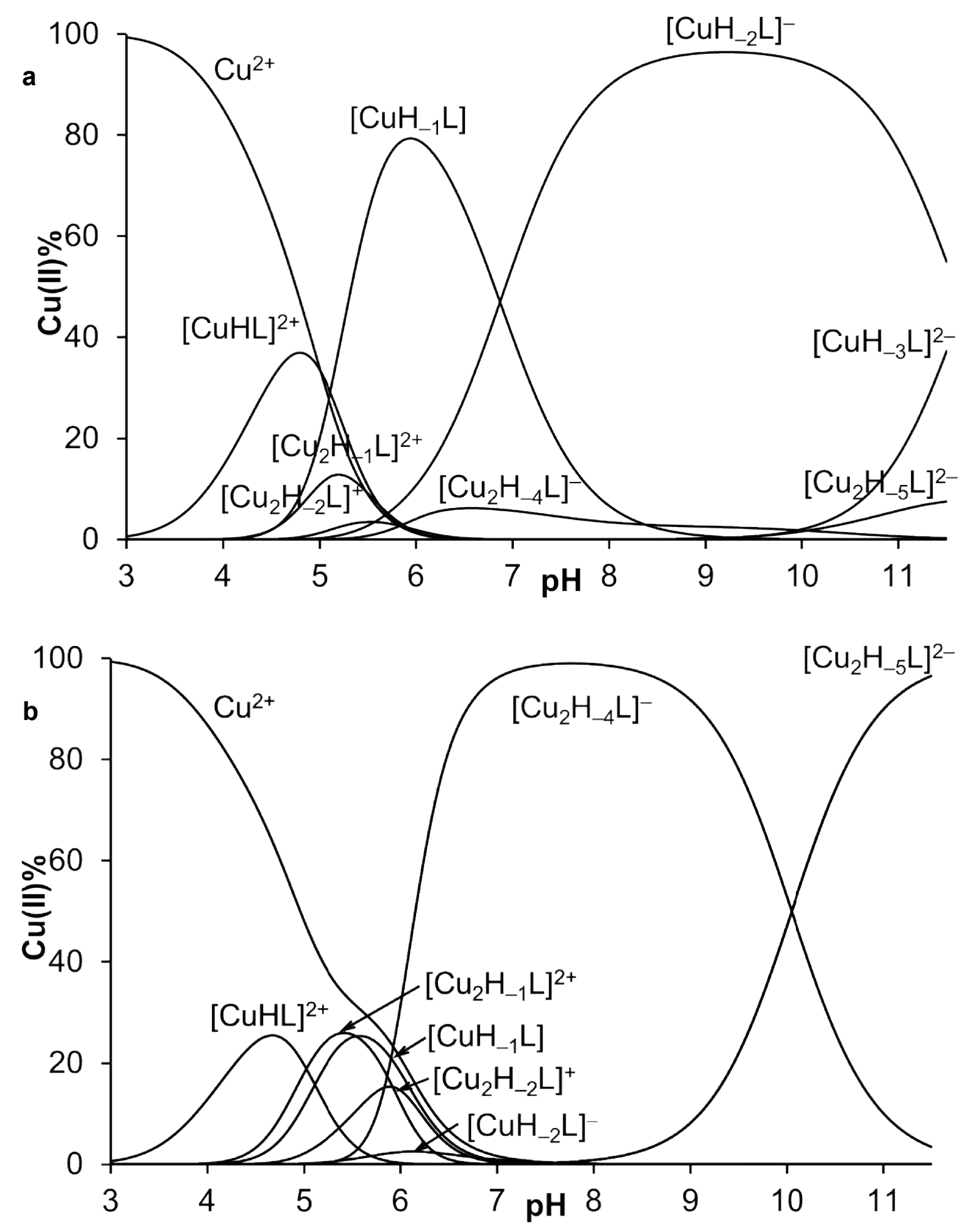

Figure 1 


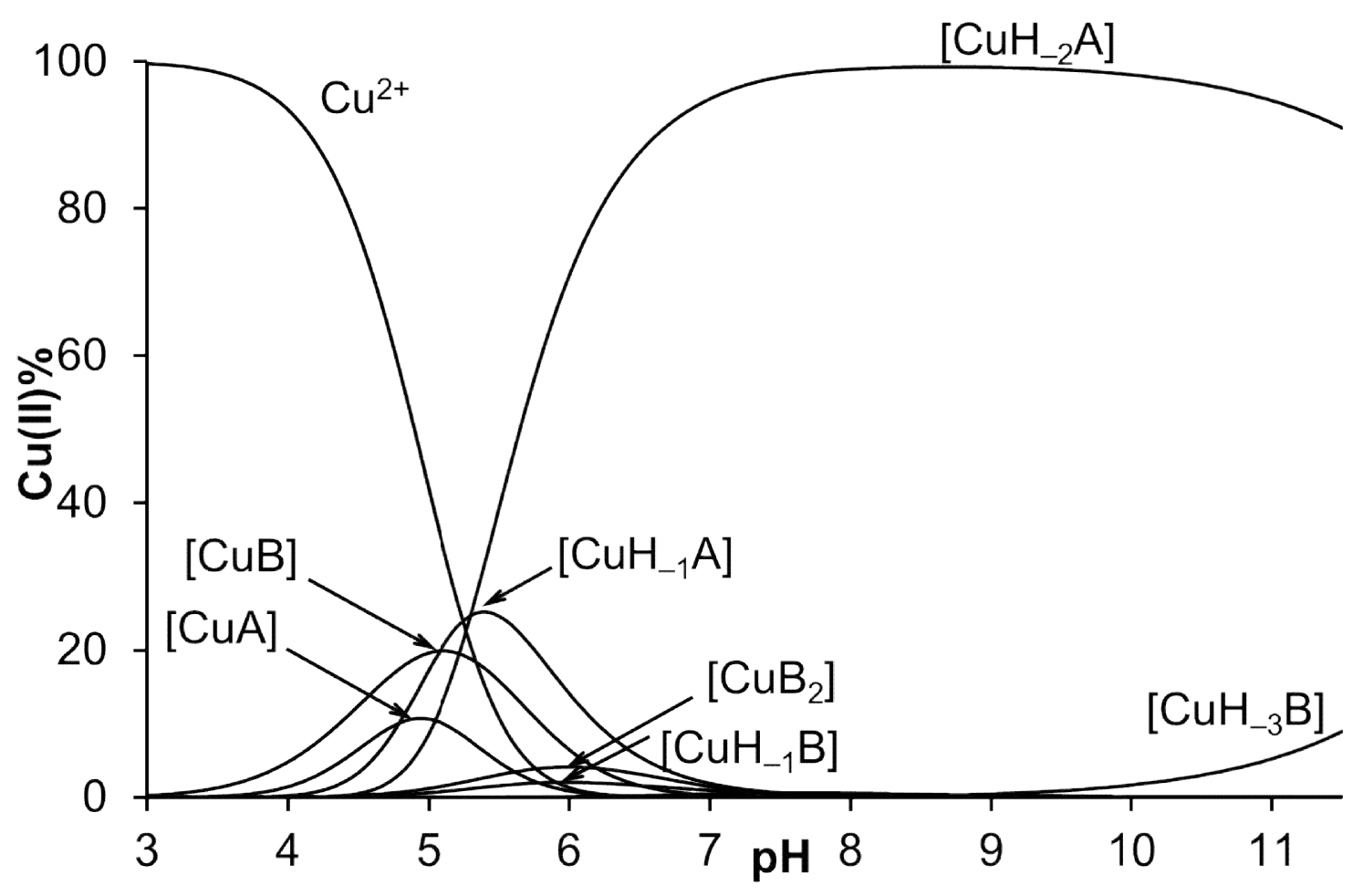

Figure 2 


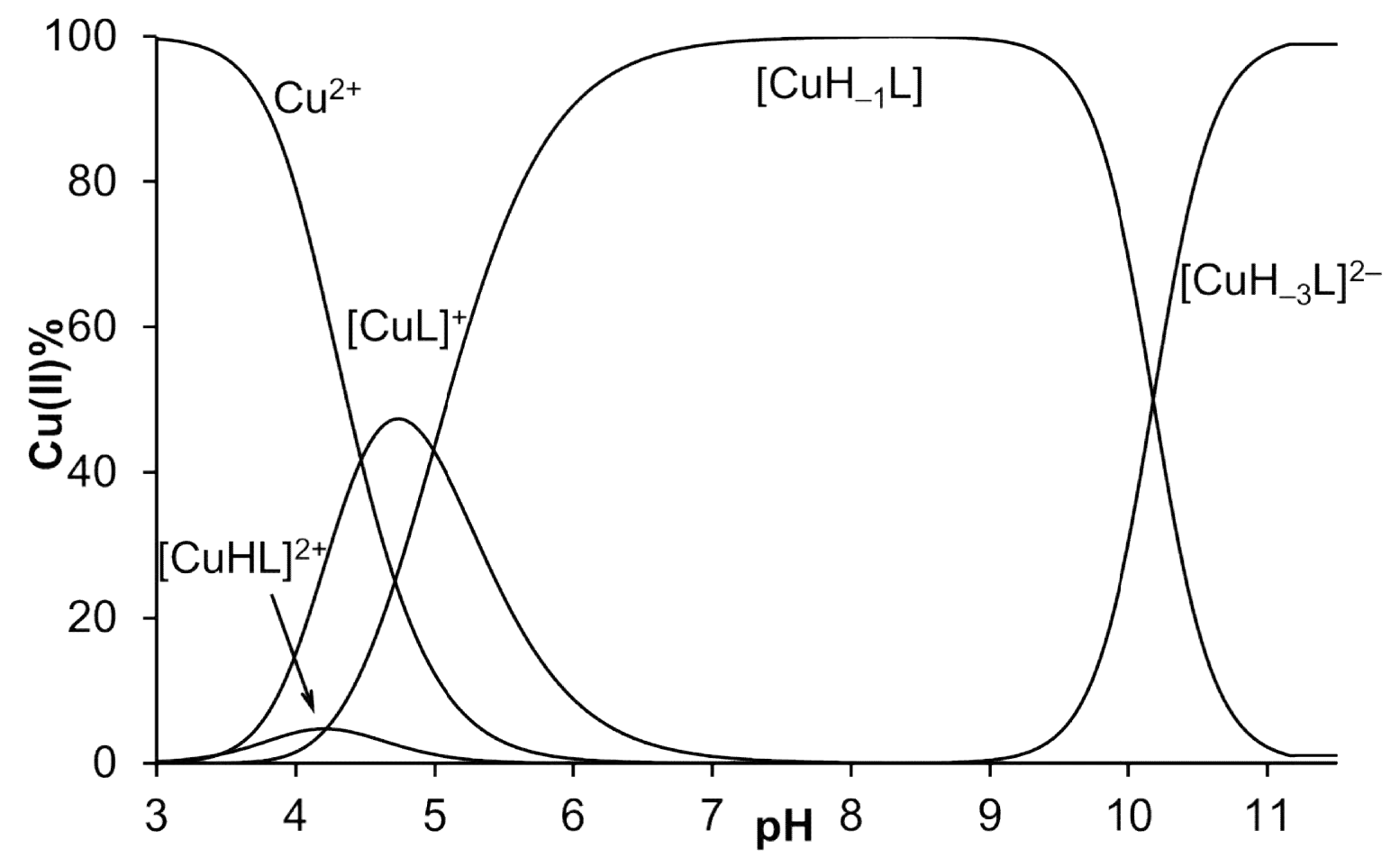

Figure 3 


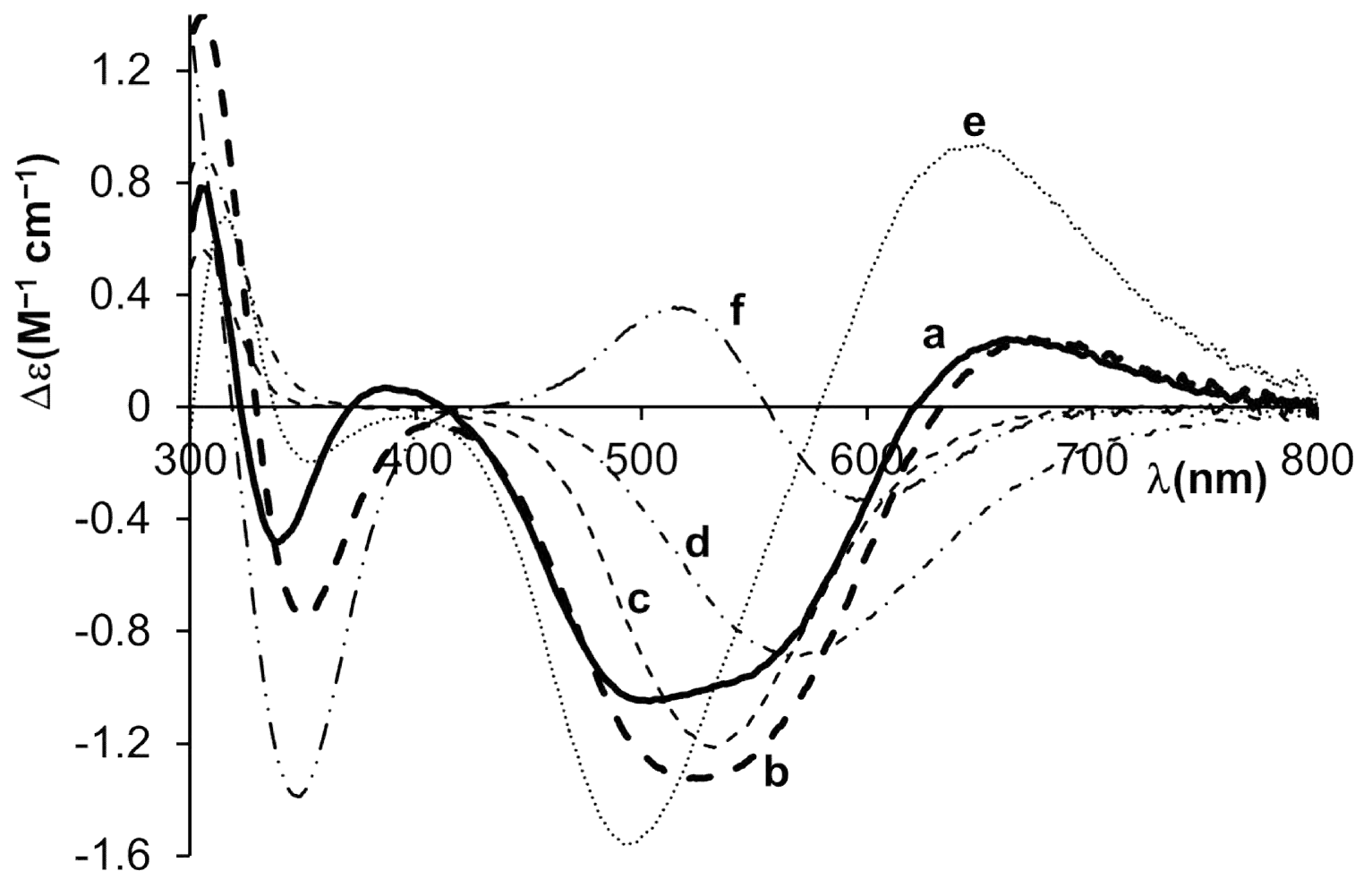

Figure 4 


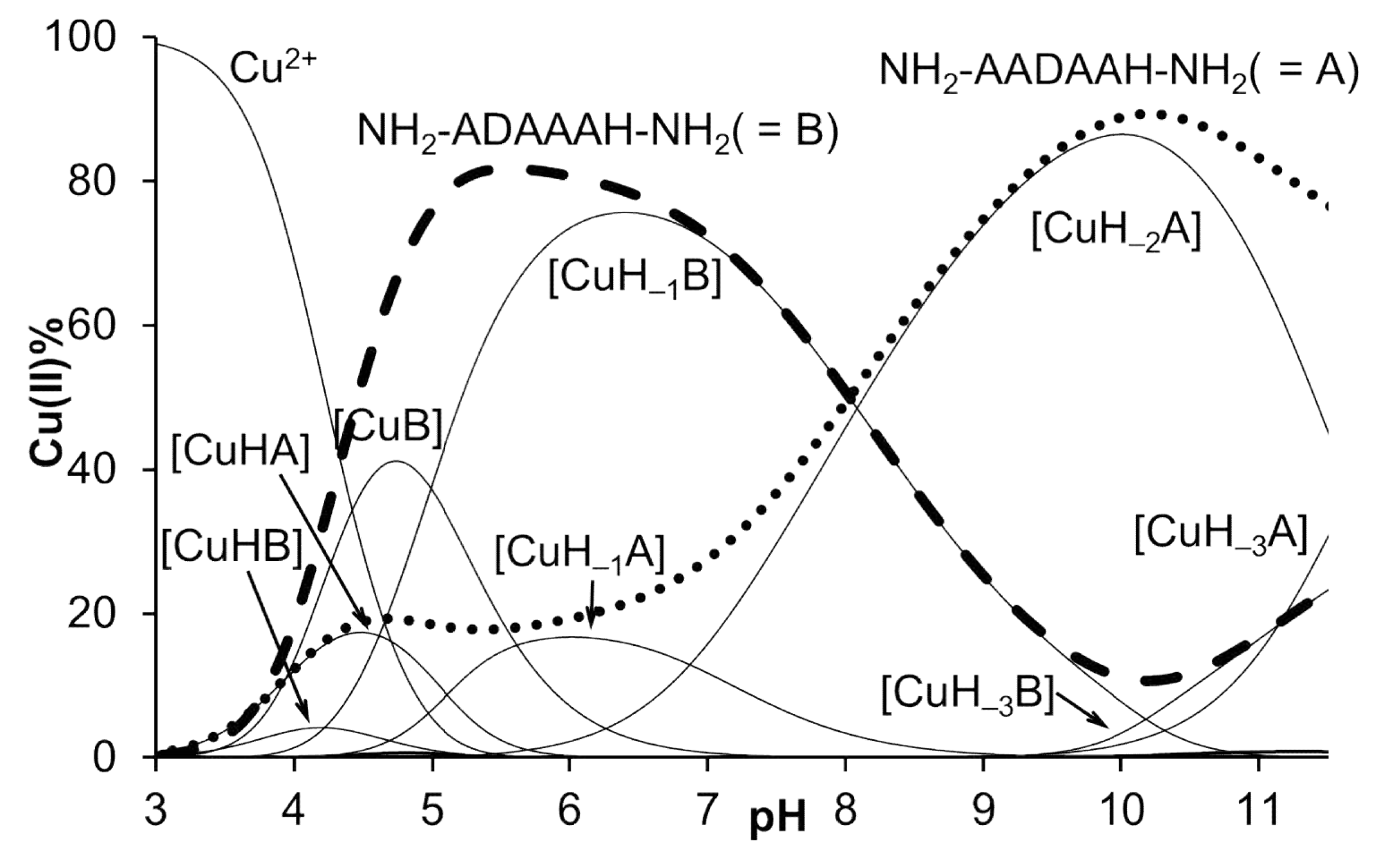

Figure 5 


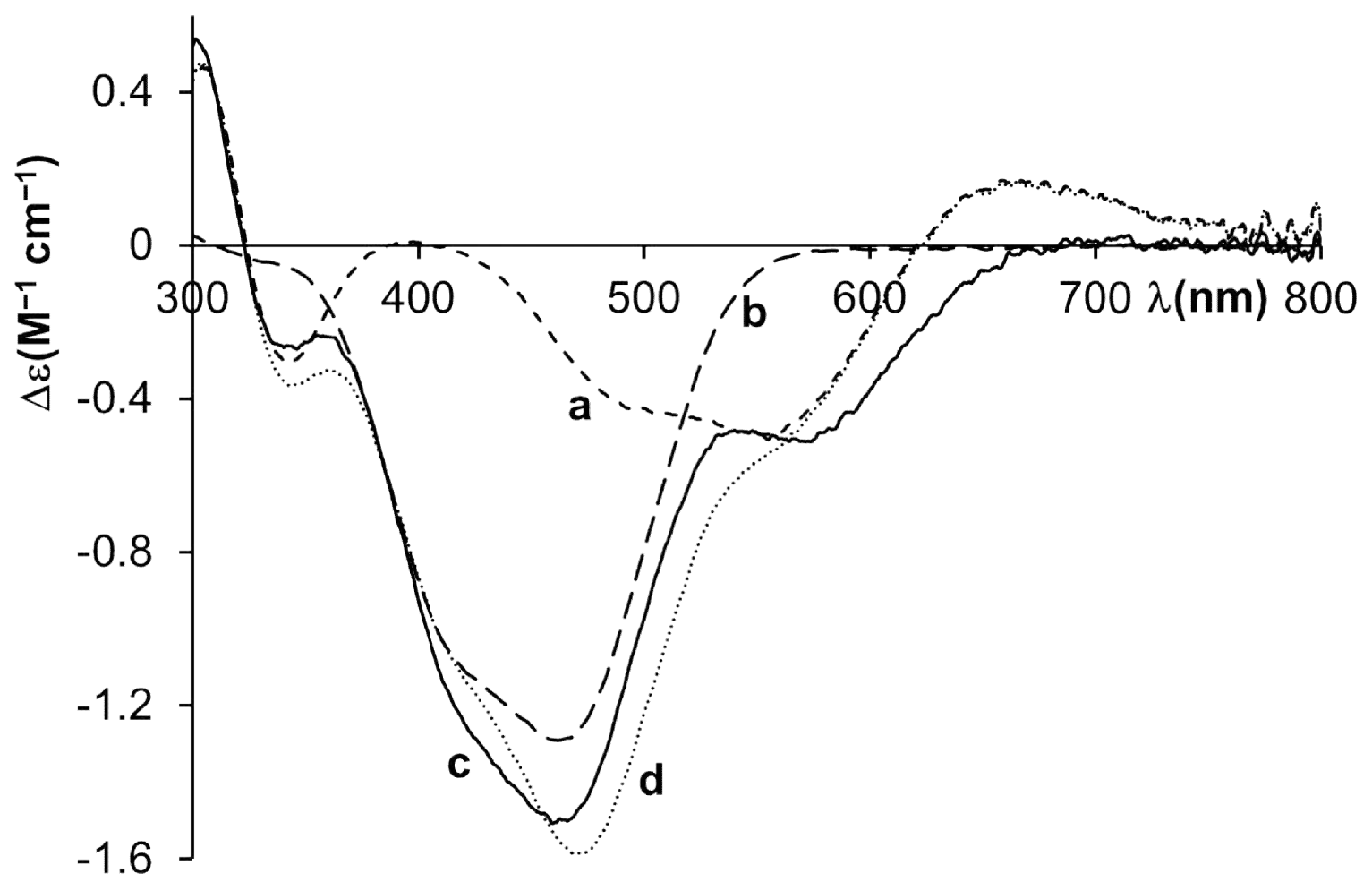

Figure 6 